\title{
Effects of processed jackfruit seed based diet on nutrient intake, digestibility and nutrition in West African dwarf goats
}

Eyoh, G. D. and Udo, M. D.

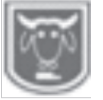

Department of Animal Science, Akwa Ibom State University, Akwa Ibom State.

Abstract

Corresponding author: gloryeyoh5@gmail.com; 07035232506

In spite of the major role of providing meat and dairy products amongst other attributes, low animal protein intake still remains a nutritional challenge. Against this background, the effect of processed jackfruit seed meal (JFSM) as a source of protein on nutrient intake, digestibility and nitrogen balance by West African dwarf goats was investigated. The seeds were processed as raw, soaked and toasted with 5\% JFSM in each processing method, incorporated in feed and designated as diets $B, C$ and $D$, while diet A devoid of JFSM served as the control. Four animals were randomly assigned to the diets in a $4 \times 4$ Latin square design experiment. The goats were each housed in a metabolic cage. Data was collected on nutrient intake, digestibility and nitrogen balance. Significant $(P<0.05)$ differences were observed in nitrogen intake $(\mathrm{g} / \mathrm{d})$, nitrogen absorbed $(\mathrm{g} / \mathrm{d})$ and nitrogen balance $(\mathrm{g} / \mathrm{d}) ; 7.37,7.45,7.40$, $7.55 \mathrm{~g} / \mathrm{d}, 3.05,3.15,3.23,3.40 \mathrm{~g} / \mathrm{d}$ and 3.66, 3.75, 3.83, 4.02g/d respectively. Similarly, apparent digestibility coefficient also showed significant difference $(P<0.05)$ in crude protein, crude fibre, ether extract and energy. Metabolic faecal nitrogen (MFN) ( $g$ ${ }^{1} 100 \mathrm{gDM}$ ) values were $1.38,0.93,0.38$ and 1.75 for diets $A, B, C$ and $D$ respectively while digestible crude protein $(D C P) g^{-1} d^{-1} W^{0.75}$ values were $2.13,5.39,2.00$ and 2.45 for diets $A$, $B, C$ and $D$ respectively. This shows that the diet enhanced nutrient intake, digestibility and nitrogen utilization, thus promoting positive nitrogen balance and maintenance in goats.

Keywords: Jackfruit seed meal, processing methods, WAD goats, digestibility, nitrogen balance.

\section{Les Effets de l'alimentation de graines de jacquier transformées sur les nutriments consumés, la digestibilité et la nutrition chez les chèvres naines d'Afrique de l'Ouest}

Eyoh, G. D. et Udo, M. D.

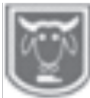

Department of Animal Science, Akwa Ibom State University, Akwa Ibom State.

Résumé

Corresponding author: gloryeyoh5@gmail.com; 07035232506

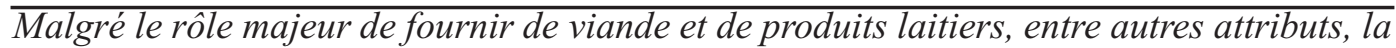
faible consommation de protéines animales reste un défi nutritionnel. Dans ce contexte, l'effet de la farine de graines de jacquier transformée en tant que source de protéines sur les nutriments consumés, la digestibilité et le bilan azoté des chèvres naines d'Afrique de l'Ouest a été étudié. Les graines ont été traitées comme crues, trempées et grillées avec 5\% de la farine de graines de jacquier transformée dans chaque méthode de traitement, incorporées dans les aliments pour animaux et désignées sous le nom de régimes $B, C$ et $D$, tandis que le régime A dépourvu de la farine de graines de jacquier transformée a servi de témoin. Quatre animaux ont été assignés au hasard aux régimes dans une expérience de conception en carré latin $4 \times 4$. Les chèvres étaient logées chacune dans une cage métabolique. Des données ont été recueillies sur l'apport en éléments nutritifs, la digestibilité et le bilan azoté. Des différences significatives $(P<0,05)$ ont été observées dans l'apport d'azote $(g / j)$, l'azote absorbé $(\mathrm{g} / \mathrm{j})$ et le bilan azoté $(\mathrm{g} / \mathrm{j})$; 7,37, 7,45, 7,40, 7,55 $\mathrm{g} / \mathrm{j}, 3,05,3,15,3,23,3,40 \mathrm{~g} / \mathrm{j}$ et 
3,66, 3,75, 3,83, 4,02 g/j respectivement. De même, le coefficient de digestibilité apparente a également montré une différence significative $(P<0,05)$ dans les protéines brutes, les fibres brutes, l'extrait d'éther et l'énergie. Les valeurs d'azote fécal métabolique (NPF) (g$1100 \mathrm{gDM}$ ) étaient respectivement de 1,38, 0,93,0,38 et 1,75 pour les régimes $A, B, C$ et $D$, tandis que les valeurs de protéine brute digestible (DCP) g-1d-1Wkg 0,75 étaient de 2,13, 5,39, 2,00 et 2,45 pour les régimes $A, B$, Cet $D$ respectivement. Cela montre que le régime a amélioré l'apport en nutriments, la digestibilité et l'utilisation de l'azote, favorisant ainsi l'équilibre et le maintien positifs de l'azote chez les chèvres.

Mots clés : farine de graines de jacquier, méthodes de transformation, chèvres WAD, digestibilité, bilan azoté.

\section{Introduction}

Goat production is a veritable way of alleviating animal protein deficiency in Nigeria. It constitutes an important part of the livelihood of livestock farmers besides offering the cheapest source of meat Tsado et al. (2009) in the tropics when compared to cattle. In spite of the major role of providing meat and dairy products amongst other attributes, low animal protein intake still remains a nutritional challenge. The main constraint to goat and other livestock production is feeding (Eyoh, 2016). Feeding accounts for up to $70 \%$ of the total cost of production. Many researchers' data have pointed out that low productivity of goats is associated with problems of meeting their nutritional requirements (Babayemi and Bamikole, 2006; Aye and Adegun, 2010; Eyoh and Ayuk, 2019). The concentrate feed made from cereal grains are becoming expensive. An alternative source of ingredients which encourages a shift to those with less competition could be used especially when there are seasonal fluctuations that affects the nutritive quality of forages and their availability during scarcity periods. Thus, the use of nonconventional feed ingredients has been known to contribute in the nutrition of ruminants thereby ensuring availability of feed at critical times. Jackfruit tree which bears jack seeds grows naturally in the wild and sometimes planted as ornamental trees around homes. Despite the nutritional potential of jackfruit, there is dearth of convincing information on its utilization for West African DwarfWAD goats. Therefore, this study evaluates nutrient intake and digestibility in WAD goats fed differently processed jackfruit seed based diets.

\section{Materials and methods \\ Location of the experiment}

The research was conducted at Teaching and Research Farm of the Department of Animal Science, Akwa Ibom State University, Obio Akpa Campus. Obio Akpa is located between latitudes $5^{\circ} 17^{\prime} \mathrm{N}$ and $5^{\circ}$ $27^{\prime} \mathrm{N}$ and between longitude $7^{\circ} 27^{\prime} \mathrm{N}$ and $7^{\circ}$ $58^{\prime} \mathrm{E}$ with an annual rainfall ranging from $3500 \mathrm{~mm}-5000 \mathrm{~mm}$ and average monthly temperature of $25^{\circ} \mathrm{C}$ with relative humidity between $60-90 \%$. It is in the tropical rainforest zone of Nigeria (SLUS-AK, 1989).

\section{Experimental animals and their management}

Four West African dwarf bucks 6-9 months were used for the experiment. The animals were purchased from a reputable sheep and goat farm in Abak village and quarantined for two weeks in the farm; dewormed with Albendazole and also treated against ecto-parasites. The animals were managed intensively before confirmed to individual metabolic crates.

\section{Experimental feed and design}

The diets consisted of processed jackfruit seeds (raw, soaked and toasted); in addition to other feed ingredients. The fresh jackfruit seeds were manually removed from the 


\section{Eyoh and Udo}

pods and divided into three groups for processing.

\section{Processing}

For raw; $1 \mathrm{~kg}$ of the jackfruit seed was sun dried for 60 minutes. Soaking; $1 \mathrm{~kg}$ of the seed was soaked in 2 litres of water for 60 minutes on a hot plate was also carried out. All the groups were milled (5\% each) and used for formulation (Table 1) with group A (Control) with 0\% JFS. Digestibility and nitrogen balance studies were carried out in a 4x4 Latin square arrangement with 4 periods each of 10 days of adjustment periods and 5 days for collection of samples. The animals were weighed and housed individually in a clean disinfected metabolism cages which is ideal for faecal and urine collection. The diets designated $A$
$-D$, were offered daily to the animals at $3 \%$ of their body weight. Water was provided ad libitum. At the expiration of 10-day adjustment to the new environment, measurements were taken for a period of five consecutive days. Left over was weighed and recorded daily before morning feeding.

Total faecal output collected daily in the morning for 5 days was weighed, mixed thoroughly, bulked and sub-sampled. Further bacterial activity was prevented by adding twenty $(20 \%)$ formaldehyde and then stored at $-4^{\circ} \mathrm{C}$. Total urine output for 24 hours was collected in plastic containers containing $10 \mathrm{mls} 0.1 \mathrm{NH}_{2} \mathrm{SO}_{4}$ which were placed under the metabolic crates. Ten percent $(10 \%)$ of daily urine output taken

Table 1: Composition of experimental diets

\begin{tabular}{lllll}
\hline Ingredients & A(control) & B(raw) & C(soaked) & D(toasted) \\
\hline Brewer's spent grain & 20.00 & 15.00 & 15.00 & 15.00 \\
Rice meal & 20.00 & 20.00 & 20.00 & 20.00 \\
Palm kernel cake & 20.00 & 20.00 & 20.00 & 20.00 \\
Cocoyam & 0.00 & 5.00 & 5.00 & 5.00 \\
Rice bran & 36.00 & 36.00 & 36.00 & 36.00 \\
Oyster shell & 2.00 & 2.00 & 2.00 & 2.00 \\
Limestone & 1.50 & 1.50 & 1.50 & 1.50 \\
Salt & 0.50 & 0.50 & 0.50 & 0.50 \\
Total & 100 & 100 & 100 & 100 \\
Calculated composition: & & & & \\
Protein (\%) & 13.82 & 14.20 & 14.12 & 14.05 \\
Energy (kcal/kg) & 2037.6 & 3746.4 & 2712.5 & 2589.6 \\
Dry matter (\%) & 89.71 & 89.78 & 89.47 & 89.58 \\
Crude protein (\%) & 15.73 & 15.64 & 15.84 & 15.53 \\
Ether extract (\%) & 3.78 & 3.86 & 4.02 & 3.74 \\
Crude fibre (\%) & 9.66 & 9.77 & 9.57 & 10.14 \\
Ash(\%) & 8.91 & 9.48 & 8.68 & 8.81 \\
NFE(\%) & 51.65 & 51.25 & 51.36 & 51.37 \\
G.E(kcal/kg) & 3.98 & 3.99 & 3.97 & 3.99 \\
\hline
\end{tabular}

Table 2: Proximate composition of experimental diets, Andropogon tectorum

\begin{tabular}{llllll}
\hline Parameters & A(control) & B(raw) & C(soaked) & D(toasted) & $\begin{array}{l}\text { Andropogon } \\
\text { tectorum }\end{array}$ \\
\hline Dry matter (\%) & 89.85 & 89.96 & 90.06 & 90.10 & 94.00 \\
Crude protein (\%) & 15.44 & 15.64 & 15.52 & 15.84 & 11.20 \\
Ether extract (\%) & 3.84 & 3.95 & 4.06 & 4.10 & 25.00 \\
Crude fibre (\%) & 9.51 & 9.44 & 9.60 & 9.37 & 3.20 \\
Ash (\%) & 5.27 & 5.21 & 5.36 & 5.24 & 12.50 \\
Nitrogen free extract & 55.80 & 55.73 & 5.36 & 5.24 & 12.50 \\
Gross energy (kcal/kg) & 4.02 & 4.03 & 4.01 & 4.03 & 18.4 \\
\hline
\end{tabular}


from each buck was stored in a refrigerator for analysis.

\section{Proximate analysis}

Feed samples were oven-dried at $70^{\circ} \mathrm{C}$ for 48 hours and milled through a $2.5 \mathrm{~mm}$ sieve. Dry matter content of the dried feed samples and faeces were determined by drying at $60{ }^{\circ} \mathrm{C}$ for 48 hours. Nitrogen content of the feed samples and urine were determined using AOAC (2000) procedures. Similarly, ether extract and crude fibre of the samples were analyzed according to AOAC (2000) procedure, while the other samples were charred in muffle furnace at $500^{\circ} \mathrm{C}$ for about 3 hours.

\section{Statistical analysis}

Data collected during feeding and digestibility were subjected to a one-way analysis of variance (ANOVA) procedure (AOAC, 2000). Duncan's Multiple Range Test (DMRT) was used to compare treatment means where there were significant differences (Duncan, 1955).

\section{Results and discussion}

The dry matter intake, nitrogen intake, digestibility and nitrogen balance by WAD goats fed processed jackfruit seed meal are presented in Table 3. There were significant $(\mathrm{P}<0.05)$ differences observed in all the parameters except for final weight. The values for dry matter intake (DMI) were $63.75,69.17,54.17$ and $52.97 \mathrm{~g} /$ day. The least value $(52.97 \mathrm{~g} /$ day $)$ was obtained in $\operatorname{diet} \mathrm{D}$ (toasted). Dry matter intake (DMI) is an important factor determining the utilization of feed in ruminants which simply referred to critical determinant of energy intake (Devendra, 1997). Feed intake on the other, is a measure of diet appreciation, collection and consumption by an animal (Masafu, 2006). Processing methods may also affect intake as observed in this study where the DMI showed no consistent trend but recorded the least in diet D (toasted). However, the crude protein intake increased with the processing methods which is in line with observation of Hwangbo et al. (2009) that increasing or decreasing crude protein intake levels had no significant effect on dry matter intake. Nitrogen intake values showed a consistent trend as they increased across the treatments for processing as compared to the control group. The values were 7.37, $7.45,7.40$ and 7.55 for diets A - D respectively. These values were however lower than 13.28 - 15.68 reported for WAD goats fed mucuna seed meal (Ukpabi, 2007). It was evident from the result of this study that the processing method employed to reduce the anti-nutritional factors of jackfruit seed was effective, hence enhanced nutrient intake. Nitrogen in faeces for the processing methods were comparable with the control diet. The highest faecal nitrogen obtained in goats on diet B (raw) could probably be due to the crude protein content that was not well utilized and thus excreted. This conforms with the report of Kerchgessner et al. (2001) that nitrogen consumed in excess of animal requirement was excreted in urine and faeces. The N-urine value (g per day) obtained in this study ranged from $0.59 \mathrm{~g} /$ day $-0.61 \mathrm{~g} /$ day. The $\mathrm{N}$-urine values were also comparable across the treatment groups. This may have been due to a reflection of nitrogen in the rumen that depends on the quality and solubility of the diets, which might have been lost from the rumen as ammonia and converted to urea before being excreted as urine. The Nbalance and $\mathrm{N}$-absorbed followed a similar trend of increase across the treatment groups. The values ranged from $3.05-$ $3.40 \mathrm{~g} / \mathrm{day}$ and $3.66-4.02 \mathrm{~g} / \mathrm{day}$ 


\section{Eyoh and Udo}

respectively. The highest values $(3.40 \mathrm{~g} / \mathrm{day}$ and $4.02 \mathrm{~g} /$ day) were recorded in toasted processing method respectively. Nitrogen absorbed is the proportion of nitrogen utilized by farm animals for body process from nitrogen intake hence more nitrogen consumed and digested also results in more nitrogen being absorbed. Okeniyi et al. (2010) reported that this observation might have been as a result of the amount of nitrogen used in protein deposition and nitrogen utilization in the rumen. The relationship between faecal nitrogen $\left(\mathrm{gK}^{-}\right.$ ${ }^{1} \mathrm{DM}$ ) and $\mathrm{N}$-intake (gday $\left.{ }^{-1}\right)$ is shown in Table 4. Except for diet $\mathrm{C}$ which was not significant, other jackfruit seed meal processing methods had higher coefficient of correlation than $\operatorname{diet} \mathrm{A}$ and were also significant. The intercept of the line relating faecal nitrogen to $\mathrm{N}$-intake gave the nitrogen excreted in faeces for each diet when the nitrogen intake was hypothetically zero, i.e. the (MFN) metabolic faecal nitrogen. The mean MFN

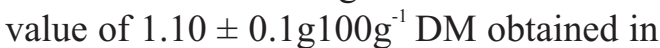
this study for jackfruit seed meal based diets is slightly higher than $0.97 \pm 0.88 \mathrm{gN}^{-1} 100 \mathrm{~g}$ DM reported by these researchers (Akinsonyinu, 1974; Odoemelam et al., 2005; Ukpabi, 2007).

Table 3: Dry matter intake and nutrient digestibility of WAD goats fed processed jackfruit seed meal

\begin{tabular}{|c|c|c|c|c|c|}
\hline Parameters & $\mathbf{A}$ & B & $\mathbf{C}$ & D & SEM \\
\hline Final weight (kg) & 7.20 & 7.40 & 7.20 & 7.87 & 1.10 \\
\hline Finale weight $\left(\mathrm{kg}^{0.75}\right)$ & 4.90 & 4.47 & 4.39 & 4.68 & 0.05 \\
\hline DMI (g/day) & $63.75^{\mathrm{b}}$ & $69.17^{\mathrm{a}}$ & 54.17 & $52.97^{\mathrm{c}}$ & 1.20 \\
\hline DMI $\left(\mathrm{W} / \mathrm{kg}^{0.75}\right)$ & $22.56^{\mathrm{b}}$ & $23.65^{\mathrm{a}}$ & $19.97^{\mathrm{c}}$ & $19.63^{\mathrm{c}}$ & 0.04 \\
\hline $\mathrm{CP}$ intake $(\mathrm{g} / \mathrm{d})$ & $54.47^{\mathrm{d}}$ & $55.90^{\mathrm{c}}$ & $57.00^{\mathrm{b}}$ & $59.70^{\mathrm{a}}$ & 0.46 \\
\hline $\mathrm{N}$-intake $(\mathrm{g} / \mathrm{d})$ & $7.37^{\mathrm{c}}$ & $7.45^{\mathrm{b}}$ & $7.40^{\mathrm{c}}$ & $7.55^{\mathrm{a}}$ & 0.02 \\
\hline $\mathrm{N}$-faeces $(\mathrm{g} / \mathrm{d})$ & $3.71^{\mathrm{a}}$ & $3.69^{\mathrm{a}}$ & $3.57^{b}$ & $3.53^{\mathrm{c}}$ & 0.00 \\
\hline $\mathrm{N}$-urine $(\mathrm{g} / \mathrm{d})$ & $0.61^{\mathrm{a}}$ & $0.60^{\mathrm{b}}$ & $0.59^{\mathrm{b}}$ & $0.61^{\mathrm{a}}$ & 0.43 \\
\hline N-absorbed $(\mathrm{g} / \mathrm{d})$ & $3.05^{\mathrm{d}}$ & $3.15^{\mathrm{c}}$ & $3.23^{\mathrm{b}}$ & $3.40^{\mathrm{a}}$ & 0.03 \\
\hline N-balance $(\mathrm{g} / \mathrm{d})$ & $3.66^{\mathrm{d}}$ & $3.75^{\mathrm{c}}$ & $3.83^{\mathrm{b}}$ & $4.02^{\mathrm{a}}$ & 0.03 \\
\hline N-balance $\left(\mathrm{g} / \mathrm{d} / \mathrm{Wkg}^{0.75}\right)$ & $2.31^{\mathrm{c}}$ & $1.37^{\mathrm{c}}$ & $2.41^{\mathrm{b}}$ & $2.51^{\mathrm{a}}$ & 0.02 \\
\hline $\mathrm{N}$-intake $\left(\mathrm{g} / \mathrm{d} / \mathrm{Wkg}^{0.75}\right)$ & $4.47^{b}$ & $4.51^{\mathrm{a}}$ & $4.49^{b}$ & $4.55^{\mathrm{c}}$ & 0.01 \\
\hline N-absorbed $\left(\mathrm{g} / \mathrm{d} / \mathrm{Wkg}^{0.75}\right)$ & $2.65^{d}$ & $2.70^{\mathrm{c}}$ & $2.74^{\mathrm{b}}$ & $2.83^{\mathrm{a}}$ & 0.02 \\
\hline Apparent digestibility \% & $49.68^{c}$ & $50.38^{\mathrm{c}}$ & $51.67^{\mathrm{b}}$ & $53.22^{\mathrm{a}}$ & 0.44 \\
\hline
\end{tabular}

a, b, $\mathrm{c}$ means in a row with different superscripts are significantly $(\mathrm{P}<0.05)$ different.

SEM: Standard Error of Mean

Table 4: Regression equation between faecal-N(g/d) (Y) and N-intake (g/d) (X) in WAD goats fed processed jackfruit seed meal

\begin{tabular}{llllll}
\hline Diets & Regression equation & $\begin{array}{l}\text { Correlation } \\
\text { coefficient }{ }^{\circledR}\end{array}$ & $\begin{array}{l}\text { Standard } \\
\text { error }(\mathbf{S E})\end{array}$ & $\begin{array}{l}\text { Faecal -N at } \\
\text { zero N-intake }\end{array}$ & $\begin{array}{l}\text { MFN } \\
\text { (g/100gDM) }\end{array}$ \\
\hline $\mathrm{A}$ & $\mathrm{Y}=13.79-1.37 \mathrm{X}$ & $0.923^{*}$ & 0.010 & 13.79 & 1.38 \\
$\mathrm{~B}$ & $\mathrm{Y}=1.75 \mathrm{X}-9.34$ & $0.986^{*}$ & 0.004 & 9.34 & 0.93 \\
$\mathrm{C}$ & $\mathrm{Y}=100 \mathrm{X}-3.83$ & $1.000^{\mathrm{NS}}$ & 0.000 & 3.83 & 0.38 \\
$\mathrm{D}$ & $\mathrm{Y}=2.76 \mathrm{X}-17.32$ & $0.974^{*}$ & 0.011 & 17.32 & 1.75 \\
\hline
\end{tabular}

MFN: Metabolic faecal nitrogen; ${ }^{\text {NS }}=$ not significant. 
The relationship between urinary- $\mathrm{N}$ (g/day $\mathrm{Wkg}^{0.75}$ ) is presented in Table 5. The two parameters considered here in this study were positively correlated except for $\operatorname{diet} \mathrm{C}$. The coefficients of correlation were 0.986 , $0.143,1.000$ and 0.974 for diets A - D respectively. Similarly, the endogenous urinary nitrogen (EUN) values were 4.08, 3.08, 3.13 and 1.81 for diets A, B, C and D respectively. The intercepts on the urinary$\mathrm{N}$ axis gave the urinary- $\mathrm{N}$ at zero $\mathrm{N}-$ absorption which is the EUN. Akinsonyinu (1974) reported that variation in the value of EUN observed within the breed may be due to urea recycling effect and this is also suggested by previous authors (Onwuka et al., 1985; Eyoh, 2016). Indicated in Table 6 is the relationship between balance $\left(\mathrm{g}^{-1}\right.$ day
$\mathrm{Wkg}^{0.75}$ ) and absorbed nitrogen. There was high correlation in the two parameters for all the diets with diets $\mathrm{B}$ and $\mathrm{D}$ being significant. The gradient of line relating Nbalance to absorbed nitrogen showed the biological value (BV) while the absorbed $\mathrm{N}$ at zero N-balance multiplied by a factor 6.25, gave the digestible crude protein (DCP) requirement Mba et al. (1975) for maintenance. The comparable biological values recorded in this study is indicative of better utilization of $\mathrm{N}$ across treatments. Meanwhile, the mean value of DCP $2.99 \mathrm{~g}$ $\mathrm{DCP}^{-1} \mathrm{Wkg}^{0.75}$ obtained in this study is higher than $1.7 \mathrm{~g} \mathrm{DCP}^{-1} \mathrm{Wkg}^{0.75}$ Hadjipanayiotou (1988) and 0.51gday ${ }^{1} \mathrm{Wkg}^{0.75}$ Onwuka et al. (1985) for WAD goats.

Table 5: Regression and correlation coefficients between urinary nitrogen $(\mathrm{g} / \mathrm{d})(\mathrm{Y})$ and

\begin{tabular}{llllll}
\multicolumn{5}{c}{ absorbed nitrogen $\left(\mathbf{g} / \mathbf{d} / \mathbf{W k g}^{\mathbf{0}} \mathbf{. 7 5}\right)(\mathbf{X})$ in } & WAD goats fed processed jackfruit seed meal \\
\hline Diets & Regression equation & $\begin{array}{l}\text { Correlation } \\
\text { coefficient } ~\end{array}$ & $\begin{array}{l}\text { Standard } \\
\text { error }(\mathbf{S E})\end{array}$ & $\begin{array}{l}\text { Faecal }-\mathbf{N} \text { at } \\
\text { zero N-intake }\end{array}$ & $\begin{array}{l}\text { MFN } \\
(\mathbf{g} / \mathbf{1 0 0 g D M})\end{array}$ \\
\hline $\mathrm{A}$ & $\mathrm{Y}=4.08-3.5 \mathrm{X}$ & $0.986^{*}$ & 0.004 & 4.08 & 4.08 \\
$\mathrm{~B}$ & $\mathrm{Y}=3.08-1.0 \mathrm{X}$ & $-0.143^{*}$ & 0.020 & 3.08 & 3.08 \\
$\mathrm{C}$ & $\mathrm{Y}=3.13-1.0 \mathrm{X}$ & $1.000^{\mathrm{NS}}$ & 0.000 & 3.13 & 3.13 \\
$\mathrm{D}$ & $\mathrm{Y}=1.81+2.5 \mathrm{X}$ & $0.974^{*}$ & 0.004 & 1.81 & 1.81 \\
\hline
\end{tabular}

$\mathrm{EUN}=$ Endogenous urinary nitrogen; ${ }^{\mathrm{NS}}=$ not significant

Table 6: Regression analysis and correlation coefficients between nitrogen balance (g/d/W kg $\left.{ }^{0.75}\right)$ $(\mathrm{Y})$ and absorbed nitrogen $\left(\mathrm{g} / \mathrm{d} / \mathrm{Wkg}^{0.75}\right)(\mathrm{X})$ in WAD goats fed processed $\mathrm{j}$ ackfruit seed meal

\begin{tabular}{cllllll}
\hline Diets & Regression equation & $\begin{array}{l}\text { Correlation } \\
\text { coefficient }(\mathrm{r})\end{array}$ & $\begin{array}{l}\text { Standard } \\
\text { error }\end{array}$ & $\begin{array}{l}\mathrm{N}- \\
\text { absorbed at } \\
\text { zero - N } \\
\text { balance }\end{array}$ & $\begin{array}{l}\text { Biological } \\
\text { value }(\mathrm{BV})\end{array}$ & $\begin{array}{l}\text { DCP for } \\
\text { maintenance } \\
\left(\mathrm{g} / \mathrm{d} / \mathrm{Wkg}^{0.75}\right)\end{array}$ \\
\hline $\mathrm{A}$ & $\mathrm{Y}=0.340+1.00 \mathrm{X}$ & $1.000^{\mathrm{NS}}$ & 0.000 & 0.340 & 0.96 & 2.13 \\
$\mathrm{~B}$ & $\mathrm{Y}=1.50 \mathrm{X}-0.862$ & $0.929^{*}$ & 0.004 & 0.862 & 0.96 & 5.39 \\
$\mathrm{C}$ & $\mathrm{Y}=0.320+1.00 \mathrm{X}$ & $1.000^{\mathrm{NS}}$ & 0.000 & 0.320 & 0.96 & 2.00 \\
$\mathrm{D}$ & $\mathrm{Y}=0.392+0.974 \mathrm{X}$ & $0.896^{*}$ & 0.008 & 0.392 & 0.97 & 2.45 \\
\hline
\end{tabular}

$\mathrm{DCP}=$ Digestible crude protein, ${ }^{\mathrm{NS}}=$ not significant

Table 7 reveals the dry matter (DM) and nutrient digestibilities of WAD goats fed processed jackfruit seed meal based diets. There were significant $(\mathrm{P}<0.05)$ differences in the apparent digestibility of dietary CP, CF, EE and Gross energy except for DM and NFE. The dry matter digestibility though not significantly different were comparable among the treatment groups with the highest $(87.63 \%)$ value obtained in diet $\mathrm{D}$ (toasted). This may have been that toasting enhanced palatability of the meal hence increase in intake. Dry matter digestibility is negatively correlated with dry matter intake (McDonald et al., 1995). The values for 


\section{Eyoh and Udo}

crude protein digestibility were 48.33, 47.11, 49.95 and 50.08 for diets A, B, C and $\mathrm{D}$ respectively. The result reveals that jackfruit seed meal based diets had better crude protein digestibility than diet A except for diet B. The highest crude protein digestibility coefficient $(50.08 \%)$ was obtained in diet D. This implies that jackfruit seed meal enhanced digestibility of crude protein. Crude fibre digestibility and ether extract digestibility followed a consistent trend. The values were 50.80, $50.28,50.01,52.72$ and $55.10,57.39,57.28$ and 56.64 for diets A - D respectively. Crude fibre is a component of dry matter, hence any factor affecting the dry matter also affects the crude fibre of that same feed (Ahamefule, 2005; Eyoh, 2016).

Table 7: Apparent Digestibility coefficient (\%) of WAD goats fed processed jackfruit seed meal

\begin{tabular}{llllll}
\hline Diets & $\mathrm{A}($ Control $)$ & $\mathrm{B}(\mathrm{Raw})$ & $\mathrm{C}($ Soaked $)$ & $\mathrm{D}($ Toasted $)$ & SEM \\
\hline Dry matter & 75.65 & 75.66 & 81.23 & 87.63 & 5.50 \\
Crude Protein & $48.33^{\mathrm{b}}$ & $47.11^{\mathrm{c}}$ & $49.95^{\mathrm{a}}$ & $50.08^{\mathrm{a}}$ & 0.22 \\
Crude fibre & $50.80^{\mathrm{b}}$ & $50.28^{\mathrm{b}}$ & $50.01^{\mathrm{b}}$ & $52.72^{\mathrm{a}}$ & 0.60 \\
Ether extract & $55.10^{\mathrm{b}}$ & $57.39^{\mathrm{a}}$ & $57.28^{\mathrm{a}}$ & $56.64^{\mathrm{a}}$ & 0.40 \\
NFE & 74.08 & 74.07 & 74.08 & 74.16 & 0.20 \\
Energy & $69.32^{\mathrm{c}}$ & $69.28^{\mathrm{c}}$ & $69.55^{\mathrm{b}}$ & $69.85^{\mathrm{a}}$ & 0.03 \\
\hline
\end{tabular}

$-\mathrm{a}, \mathrm{b}, \mathrm{c}$, means on the same row with different superscripts differ significantly $(\mathrm{P}<0.05)$

SEM: Standard Error of Mean

Nitrogen free extract (NFE) digestibility values which did not differ $(\mathrm{P}<0.05)$ significantly were $74.08,74.07,74.08$ and $74.16 \%$ for diets A, B, C and D respectively. The comparable NFE digestibility values in this study suggests that there was proper utilization and digestion by the animals across all the treatment groups. However, the values reported in this work contradicts with the reports of these researchers; (Onwuka and Akinsoyinu, 1985; Lamidi et al. (2010). Energy digestibility co-efficient of the diets were significant and comparable among the treatment groups. The values were $69.32,69.28,69.55$ and 69.85 for diets A, B, C and D respectively. The highest $69.85 \mathrm{kcal} / \mathrm{kg}$ was obtained in $\operatorname{diet} \mathrm{D}$.

The values for apparent $\mathrm{N}$-digestibility (\%) (Table 3) were 49.68, 50.38, 51.67, 53.22 for diets A, B, C and D respectively. The result shows that jackfruit seed based diet gave better apparent digestibility than the control diet which is plausible reason for better utilization.

\section{Conclusion}

The study showed that processed jackfruit seed meal can be included in feeding West African dwarf goats as it enhanced nutrient intake, digestibility and nitrogen utilization.

\section{References}

Ahamefule, F. O. 2005. Evaluation of Pigeon pea cassava peel based diets for goat production in South Eastern Nigeria. Ph.D Thesis. Michael Okpara University of Agriculture, Umudike, Nigeria.

Akinsoyinu, A. O. 1974. Studies on protein and energy utilization by the WAD goats. Ph.D. Thesis, University of Ibadan, Ibadan, Nigeria.

AOAC. 2000. Association of Analytical Chemist. Official Methods of Analysis $17^{\text {th }}$ Edition AOAC Ic. Arlington, Virginia, USA.

Aye, P. A. and Adegun, M. K. 2010. Digestibility and growth in West African dwarf sheep fed gliricidiabased multinutrient block supplements. Agriculture and Biology Journal of North America, 6.1133.1139. 
Babayemi, O. J. and Bamikole, M. A. 2006. Effects of Tephtosia candida Dc leaf and its mixture with Guinea grass on in vitro fermentation changes as feed for ruminants in Nigeria. Pakistan Journal of Nutrition 5(1): 14-18.

Devandra, C. 1997. Cassava as a feed source for ruminants. Proceedings of agricultural conference on cassava as animal feed. Pp $107-$ 119.

Duncan, D. B. 1955. Multiple Range and Multiple F-test Biometrics 11:1 42.

Eyoh, G. D. 2016. Performance of West African dwarf goats on some selected forage plants under five housing systems. Ph.D. dissertation. University of Calabar, Calabar, Cross River State. Nigeria.

Eyoh, G. D. and Ayuk, A. A. 2019. Growth performance and carcass characteristics of West African dwarf goats fed selected forages inAkwa Ibom State. Journal of Anim. Sc. \& Vet. Medicine, Vol4(2), 78-83.

Hwangbo, S. Choi, S. H., Kim, S. W., Son, D. S., Park, H. S., Lee, S. H. and Jo, I. H. 2009. Effects of crude protein levels in total mixed rations on growth performance and meat quality in growing Korean Black goats. Asian-Aust. J. Anim. Sci. 22(8): $1133-1139$.

Kerchgessner, M., Windisch, W. and Roth, F. X. 2001. The efficiency of nitrogen conversion in animal nutrition. Journal of Animal Science. 79: 247-253.

Lamiid, A. A., Aina, A. B. J. and Sowande, S. O. 2010. Nutrient digestibility and nitrogen balance in West African dwarf goats fed blended diets for dry season production. Proc. $35^{\text {th }}$ Conf. Nig. Soc. For Anim. Prod. 14 $14^{\text {th }}-17^{\text {th }}$ March, University of Ibadan. Pp.607.

Masafu, M. M. 2006. The evaluation of Leucaera leucocephala (Lam) DE WIT: A renewable protein supplement for low quality forages. Ph.D. Thesis, University of South Africa.

Mba, F. I. 1975. Intake and digestibility of Red Sokoto goats utilization by the WAD goats. Ph.D Thesis, University of Ibadan, Ibadan, Nigeria.

McDonald, P., R. A. Edward and J. F. D. Green halgh 1995. Animal Nutrition $5^{\text {th }}$ Ed. (Longman group Ltd) London.

Odoemelam, V. U., Ahiwe, E. U., Ekwe, C. C., Obikaonu, H. O and Obi, J. I. 2005. Dry matter intake, nutrient digestibility and nitrogen balance of WAD bucks fed Panicum maximum supplemented concentrate containing Bambara nut (Vigna subterranea) meal. Nig. Journal of Agric., Food and Environment, 11(2):59-65.

Okeniyi, F. A., Aina, A. B. J., Onwuka, C. F. I. and Sowande, S. O. 2010. Nutrient digestibility of urea maize stover-based diets as dry season feed in West African dwarf goats. Proc. $15^{\text {th }}$ Conf. Animal Science Association of Nigeria. University of Uyo, Nigeria. Pg. $663-665$.

Onwuka, C. F. I. and Akinsoyinu, A. O. 1985. Protein and energy requirement of WAD goats fed browse (cassava) leaves supplemented with cassava peels. Proc. Nat. Conf. on small ruminant prod. (Abstr.) Oct, $6^{\text {th }}-11^{\text {th }}$, NAPRI, Shika, Zaria.

Onwuka, C. F. I., Akinsoyinu, A. O. and Mba, A. U. 1985. Protein and 


\section{Eyoh and Udo}

energy requirements of WAD goats fed varying levels of browse (cassava) leaves and cassava peels. (Abstract). In: Small ruminant production in Nigeria, Adu, I. F., Osinowo, O. A., Taiwo, B. B. A., and Alhassan, W. S. (Eds). Proc. of the Nat. Conf. on Small Ruminant Prod. Zaria, Nig. $6^{\text {th }}-10^{\text {th }}$ Oct. Pp 281.

SLUS-AK 1989. Soils and Land Use Studies.Government Print Office, Uyo, Akwa Ibom State.Soil Survey Staff, 1994.Keys to Soil Taxonomy. Soil Management Service (SMSS). Tech. Monogr. No. 19.30-60.
Tsado, D. N., Aremu, A., Egena, S. S. A. and Ismah, O. 2009. Assessment of body weight of Savanna brown goat, castrates, non-castrates and females using linear measurement. $34^{\text {th }}$ Annual Conf. of Nig. Soc. For Anim. Prod. Pp. $500-503$.

Ukpabi, U. H. 2007. Evaluation of mucuna seed meal based diets for goat production in South Eastern Nig. Ph.D dissertation. Michael Okpara University of Agric. Umudike, Nigeria.

Received: $5^{\text {th }}$ August, 2020

Accepted: $16^{\text {th }}$ November, 2020 